\title{
Effect of Butyric Anhydride Modification on Properties of Wood-polylactic Acid 3D-printed Composites
}

\begin{abstract}
Nasir Narlığlu*
Scotch pine wood flour was modified with butyric anhydride to determine the effect of wood modification on the properties of 3D-printed composites. The 3D printer filaments were obtained by mixing wood flour and polylactic acid (PLA) with a twin-screw extruder. The composites were printed via a 3D printer from the obtained filaments. The mechanical, thermal, and morphological properties of the composites were investigated. According to the mechanical test results, the tensile strength values of the modified wood flour (MWF)-added composites were higher than the unmodified wood flour (UMWF)-added composites. It was also observed that the flexural strength and flexural modulus of MWF-added composites decreased compared to the UMWF-added composites. According to the investigation of the thermal properties of the composites, the thermal degradation temperature value of the $20 \%$ MWF-added PLA composite was higher than other composites. Therefore, through the investigation of breaking surfaces of the composites using scanning electron microscopy, it was observed that the interface bonding between PLA polymer matrix and wood flour was improved by modification.
\end{abstract}

DOI: 10.15376/biores.17.1.132-143

Keywords: Wood modification; Butyric anhydride; Polylactic acid; 3D-printed composite

Contact information: Department of Forest Industry Engineering, Faculty of Forestry, İzmir Katip Çelebi University, İmir, Turkey; *Corresponding author: nasirnarlioglu@yahoo.com

\section{INTRODUCTION}

Today, demand for the filaments used in 3D printers is increasing due to the widespread use of such printers. The increase in demand for 3D printer filaments also causes an increase in the consumption of limited polymers (i.e., polylactic acid (PLA), polyhydroxybutyrate (PHB)). For this reason, composite filaments were obtained by reinforcing polymers with various materials (i.e., minerals, natural fibers). In contrast, some properties of natural fiber-reinforced composites (such as low interface bonding) are not at the desired level, so it is necessary to improve their properties.

It has been reported in previous studies that wood/plant fibers have been modified with various chemicals (anhydrite, isocyanate, etc.) to increase their properties such as dimensional stability and thermal and biological resistance (Hill and Jones 1999; Hill 2006; Hill et al. 2006; Rowell 2006; Çetin et al. 2011; Özmen 2012). Recently, it has been observed that studies on thermoplastic polymer reinforced with wood/plant fibers have become widespread. In addition, it has been found that the properties of composites (such as interfacial adhesion and thermal properties) were improved as a result of the addition of modified wood/plant fibers to the polymer matrix (Csizmadia et al. 2013; Wei et al. 2013; Spiridon et al. 2016; Zhang et al. 2017; Narlığlu 2018; Yang et al. 2020). The 
compatibility of PLA polymer was improved after plant fibers were treated with silane coupling agent (KH-550) (Liu et al. 2019).

Similarly, treatment of micro/nanocellulose (MNC) with silane (KH-550) has been reported to improve the compatibility of PLA (Wang et al. 2017). In addition, it has been reported that the thermal and mechanical properties of PLA are improved as a result of the addition of vinyltrimethoxysilane (VTMO) modified Sitka spruce (Picea sitchensis) wood fiber into it (Gregorova et al. 2009). In another study, the mechanical values of the composite samples were increased, and the interfacial bond between wood flour and PLA was also improved when the compatibilization agents were used in the production of 3D printer filaments (Petchwattana et al. 2019).

It has been reported that chemically modified natural reinforcing materials (wood/plant fiber and microcrystal cellulose) contribute to the improvement of the interfacial adhesion ability with thermoplastic polymers (HDPE and PP). Such results were obtained in studies on widely used thermoplastic composite production methods (press moulding and injection moulding) (Özmen et al. 2013; Çetin et al. 2015; Narlığlu 2018). For this reason, it is thought that chemically modified (with butyric anhydride) wood flour will contribute to the properties of wood-PLA composite filaments. Also, although the studies on the production and printing of wood/plant fiber-added 3D printer filaments have become widespread, studies on the composite filaments reinforced with modified (with anhydrides) natural fiber are quite limited.

This study was carried out to improve some properties (mechanical, thermal, interface bonding) of 3D composite filaments. The study consisted of three stages. In the first stage, Scotch pine wood flour was modified with butyric anhydride. In the second stage, composite filaments were produced as a result of mixing PLA polymer and wood flour in the extruder. In the last stage, test samples were printed using the 3D printer to compare the properties of modified wood flour (MWF) and unmodified wood flour (UMWF) added composite filaments with each other.

\section{EXPERIMENTAL}

\section{Materials}

For this study, Scots pine (Pinus sylvestris) wood was obtained from the Zülkadiroğulları timber company (Kahramanmaraş, Turkey). Also, butyric anhydride, dimethylformamide, potassium carbonate, acetone, toluene, and ethanol were obtained from Merck chemicals (Darmstadt, Germany) for chemical modification and extraction processes. In addition, the PLA (FKUR Bioflex ${ }^{\circledR}$ F 6513, Willich, Germany) polymer was used to produce $3 \mathrm{D}$ printer filaments.

\section{Methods}

Preparation of wood flour

Scots pine (Pinus sylvestris) wood was ground in a laboratory-type grinder (IKA MF 10, IKA-Werke GmbH \& Co. KG, Staufen, Germany). Then, the groundwood flour was classified using a vibrating sieve (LOYKA ESM 200, Akyol Trade Coll. Sti., Istanbul, Turkey). The sieved particles (177 to $250 \mu \mathrm{m})$ were oven-dried at $103 \pm 2{ }^{\circ} \mathrm{C}$ until completely dry. 


\section{Modification of wood flour}

First, wood flour was extracted with purified water and then it was extracted with a mixture of toluene-acetone-ethanol (4/1/1, volume/volume/volume) for $6 \mathrm{~h}$. The extracted wood flour was kept in an oven at $100{ }^{\circ} \mathrm{C}$ until it reached completely dry weight. Then it was cooled in a desiccator containing phosphorus pentoxide. The wood flour then was modified with butyric anhydride, dimethylformamide (DMF) solvent, and potassium carbonate catalyst at $100{ }^{\circ} \mathrm{C}$ for $6 \mathrm{~h}$ in a glass reactor. The water and solvent extractions were performed to remove unreacted chemicals in the modified wood flour (MWF). The MWF was dried in an oven at $103 \pm 2{ }^{\circ} \mathrm{C}$ until completely dry and then cooled in a desiccator containing phosphorus pentoxide. The percent weight gain (WPG) of wood flour was determined according to Eq. (1) after the modification process,

$$
W P G(\%)=\left[\left(W_{2}-W_{1}\right) / W_{1}\right] \times 100
$$

where $W_{1}$ is the weight (g) of dry wood flour prior to modification, and $W_{2}$ is the weight (g) of dry wood flour the post modification.

After the modification, 16\% WPG was calculated for wood flour.

\section{Production of $3 D$ printer filaments}

The MWF and UMWF were added to PLA at a ratio of 0 to 10 to $20 \%$ by weight for $3 \mathrm{D}$ printer filaments production (Table 1). The filaments were obtained using a twinscrew extruder (Microlab Twin Screw Extruder, Rondol, Staffordshire, UK) with a 1.75 $\mathrm{mm}$ die and a length-to-diameter ratio (L/D) of 20 . The screw speed was $50 \mathrm{rpm}$, and the barrel temperature profile (from hopper to die) was adjusted to the temperature gradient: 100 to140 to 160 to 170 to $175{ }^{\circ} \mathrm{C}$. Extruded wood flour/PLA was transformed into composite filaments of $1.75 \mathrm{~mm}$ diameter and desired length.

Table 1. Wood/PLA Composite Filament Formulation and Rates

\begin{tabular}{|c|c|c|c|}
\hline Sample ID & $\begin{array}{c}\text { PLA } \\
(\%)\end{array}$ & $\begin{array}{c}\text { UMWF } \\
(\%)\end{array}$ & $\begin{array}{c}\text { MWF } \\
(\%)\end{array}$ \\
\hline P & 100 & - & - \\
\hline PS1 & 90 & 10 & - \\
\hline PS2 & 80 & 20 & - \\
\hline MPS1 & 90 & - & 10 \\
\hline MPS2 & 80 & - & 20 \\
\hline
\end{tabular}

\section{Production of $3 D$ printed test samples}

Composite samples were printed via a 3D printer (homemade Sigma 3D (open source) printer) according to ASTM D638-14 (2014) and ASTM D790-17 (2017) standards to determine the tensile and flexural strength properties of composites. Sigma 3D (open source) printer with 0.6-mm nozzle and Repetier-Host software (Repetier-Host, Hot-world $\mathrm{GmbH}$, version 0.92.9, Willich, Germany) were used to produce test samples. A $50 \mathrm{~mm} / \mathrm{s}$ printing velocity, $0.3 \mathrm{~mm}$ layer thickness, $45^{\circ}$ raster angle, $190{ }^{\circ} \mathrm{C}$ nozzle temperature, and $100 \%$ infill density parameters were selected to print the test samples.

The experimental study flowchart is given in Fig. 1. In the first stage of the study, filaments were obtained by mixing wood flour and PLA in a twin-screw extruder. In the next stage of the study, $3 \mathrm{~mm}$ thickness tensile samples (ASTM D638, Type IV) and flexural samples were produced using a 3D printer. Six specimens were printed separately 
for tensile and flexural strength tests. Before the tests, the specimens were conditioned at a relative humidity of $65 \pm 5 \%$ and a temperature of $23 \pm 2{ }^{\circ} \mathrm{C}$ for 7 days.

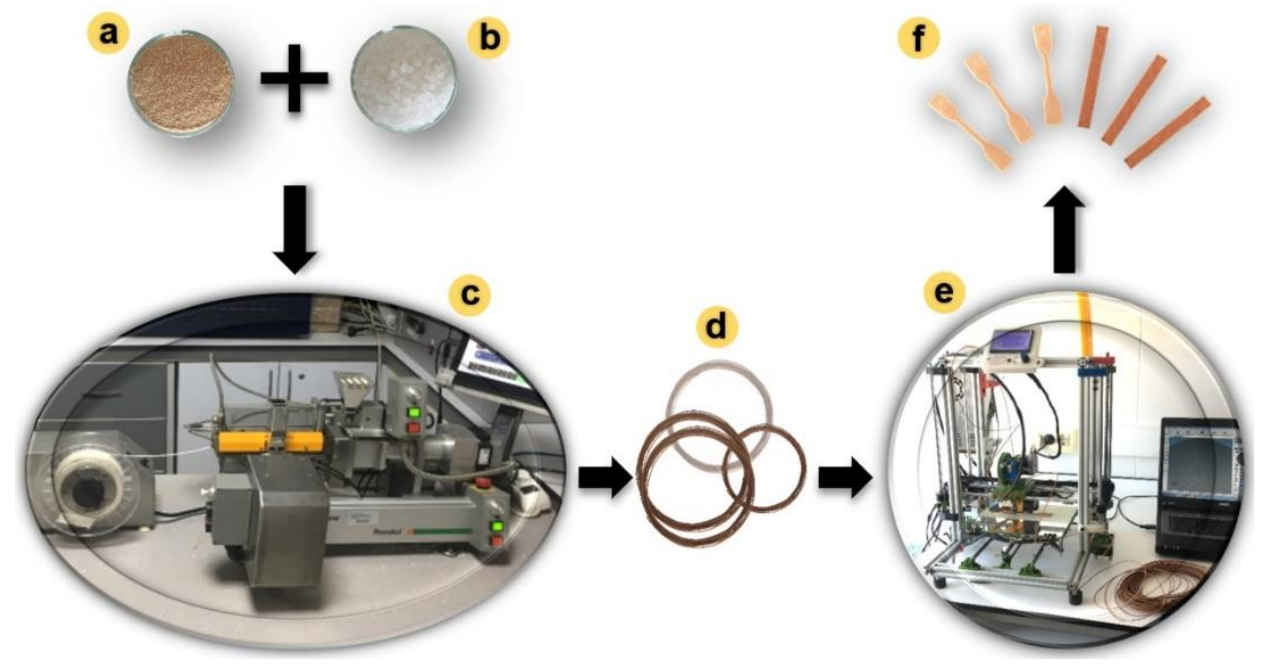

Fig. 1. Experimental flowchart, a) Wood flour, b) PLA, c) Twin-screw extruder, d) Filaments, e) 3D printer, f) 3D printed test samples

\section{Determination of mechanical properties}

Tensile and flexural strength properties of composites were determined according to ASTM standards (ASTM D638-14 (2014) and ASTM D790-17 (2017)) using an ALARGE (Istanbul, Turkey) brand $2 \mathrm{kN}$ universal testing machine.

\section{Determination of thermal properties}

The thermogravimetric analysis (TGA) and differential scanning calorimetry (DSC) analysis of the produced 3D-printed samples was performed using a thermal gravimetric analyzer (Shimadzu TA60, Kyoto, Japan) and differential scanning calorimeter (Shimadzu TA50, Kyoto, Japan), respectively. The TGA measurement was carried out between 25 and $600{ }^{\circ} \mathrm{C}$ at a heating rate of $10^{\circ} \mathrm{C} / \mathrm{min}$ in an inert nitrogen atmosphere with a flow rate of $50 \mathrm{~mL} / \mathrm{min}$. In addition, samples were heated from 25 to $250{ }^{\circ} \mathrm{C}$ for DSC measurement.

\section{Fourier transform infrared (FTIR) analysis of wood flour}

The FTIR analysis were performed using FTIR spectrometry (Agilent Cary 630 FTIR spectrometer; Agilent Technologies, Santa Clara, CA, USA) for the chemical characterization of wood flour.

\section{Morphological characterization of $3 D$ printed samples}

Electron microscope images were taken to investigate the relationship between MWF- and UMWF-added PLA polymer. The breaking surfaces of the test specimens were scanned with a scanning electron microscope (ZEISS Sigma 300 VP; Carl Zeiss Microscopy, LLC, White Plains, NY, USA) after gold plating (Q150R Plus; Quorum Technologies, Laughton, UK). 


\section{Statistical analysis}

The statistical significance of the numerical values obtained from the mechanical tests of the samples was compared with the Tukey test after analysis of variance (ANOVA) using the OriginPro 2019b program (OriginLab Corporation, Northampton, MA, USA). According to the statistical analysis results, the statistical difference $(\mathrm{p}<0.05)$ between the test samples is indicated with different small letters in the mechanical test result graphics (Figs. 3 and 4).

\section{RESULTS AND DISCUSSION}

\section{FTIR Analysis of Wood Flour}

Figure 2 shows the FTIR spectra of unmodified and butyric anhydride-modified wood flour. As can be seen in Fig. 2, the MWF showed a strong carbonyl stretching vibration $(v \mathrm{C}=\mathrm{O})$ peak at $1740 \mathrm{~cm}^{-1}$. Additionally, a decrease was observed in the intensity of the wavelength range of 3200 to $3600 \mathrm{~cm}^{-1}$ after the modification of wood flour. The increase in peak intensity at the wavelength of $1740 \mathrm{~cm}^{-1}$ and the intensity decrease of the broad $\mathrm{OH}$ peak between the wavelengths of 3200 to $3600 \mathrm{~cm}^{-1}$ were attributed to the chemical modification of the wood (Tserki et al. 2005; Wei et al. 2013). In addition to these, a peak at $1160 \mathrm{~cm}^{-1}$ was due to the $\mathrm{C}-\mathrm{O}$ stretching vibration $(v \mathrm{C}-\mathrm{O})$. Esterification reactions of lignocellulosics were supported by the emergence of a new peak in the 1162 to $1229 \mathrm{~cm}^{-1}$ wavenumber range. This is attributed to the $\mathrm{C}-\mathrm{O}$ tension of the carboxyl group as a result of esterification (Tserki et al. 2005; Narlıoğlu 2018).

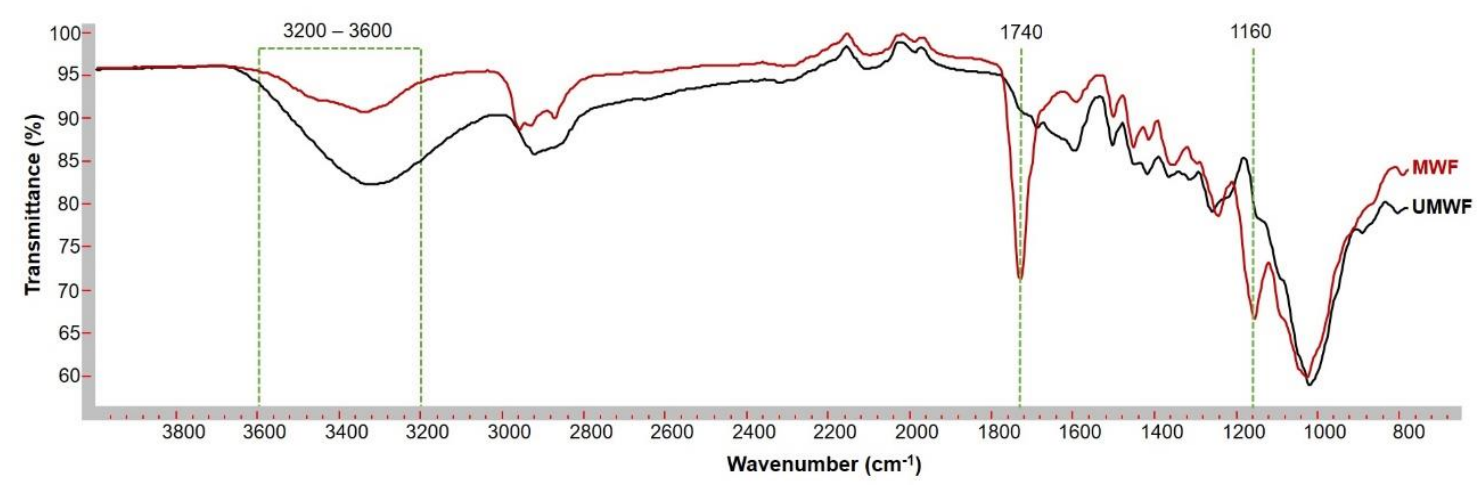

Fig. 2. The FTIR spectra of UMWF and modified MWF wood flour

\section{Mechanical Properties of 3D-printed Samples}

Figure 3 shows the tensile strength and tensile modulus of the $3 \mathrm{D}$-printed test specimens. In this study, the tensile strengths generally decreased with the addition of wood flour to neat PLA polymer. Similarly, it has been reported that the tensile strength decreases due to the weak interface bonding as a result of the addition of wood/plant fiber to the neat PLA polymer (Stoof et al. 2017; Petchwattana et al. 2019; Kain et al. 2020; Narlioğlu et al. 2021). As a result of the comparison of the tensile strengths of the composites, it was seen that the MWF-added composites (MPS1 and MPS2) showed better values than the UMWF-added composites (PS1 and PS2). In addition, the tensile modulus first decreased with the addition of $10 \%$ wood flour to PLA polymer, then it increased with the addition of $20 \%$ wood flour, and it showed similar values with that of neat PLA. Similarly, it has 
been reported that the tensile modulus first decreases and then increases as a result of adding wood flour to PLA polymer (Stoof et al. 2017; Estakhrianhaghighi et al. 2020; Narlığlu et al. 2021). The tensile strength of 3D-printed samples from neat PLA was 42.27 $\mathrm{MPa}$, and the tensile modulus was 2.27 GPa. The highest tensile strength (31.74 MPa) and tensile modulus $(2.29 \mathrm{GPa}$ ) of the composites were seen from the $20 \% \mathrm{MWF}$-added composite sample (MPS2). Additionally, the lowest tensile strength was $28.13 \mathrm{MPa}$ in the $20 \%$ UMWF-added composite sample (PS2). In addition, the lowest tensile modulus value was measured as $1.95 \mathrm{GPa}$, which was from the $10 \%$ UMWF-added composite sample (PS1). In Petchwattana et al. (2019), it was reported that the tensile strength of composites is improved as a result of adding $\gamma$-aminopropyl trimethoxy silane to the composite mixture to enhance compatibility between teak (Tectona grandis) wood flour and PLA. In another study, it was found that the tensile strength (51.5 MPa) of the PLA composite with vinyltrimethoxysilane (VTMO) modified wood fiber (Picea sitchensis) was higher than that of the UMWF-added composite (45.3 MPa) (Gregorova et al. 2009).

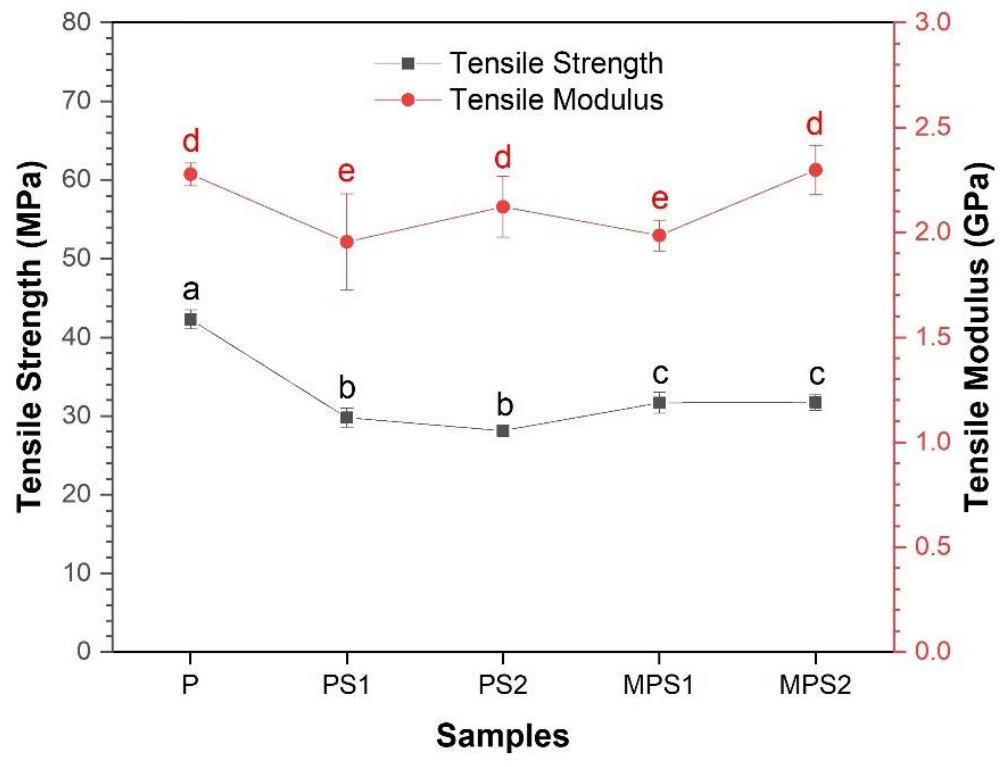

Fig. 3. Tensile strength and modulus of 3D-printed samples

Figure 4 shows the flexural strength and flexural modulus of the 3D-printed samples. The flexural strength decreased with the addition of wood flour to the neat PLA polymer. Similarly, it was indicated that the flexural strength decreased as a result of adding wood flour/plant fiber to PLA polymer (Narlıoglu et al. 2021; Yang et al. 2021). It was reported that the flexural strength decreases with the addition of kenaf fiber to neat PLA and this decrease is due to the poor adhesion between kenaf fibers and PLA (Huda et al. 2008). It was seen that the flexural modulus generally increased with the addition of wood flour to PLA polymer. In addition, the flexural modulus value of the MWF-added composites showed a slight decrease compared to the unmodified ones. The increase in flexural modulus with the addition of wood flour to PLA is an expected increase due to the high flexural modulus of wood (Petchwattana and Covavisaruch 2014). The highest flexural strength (66.85 MPa) and flexural modulus (3.07 GPa) among the composites was seen in the 10\% UMWF-added composite sample (PS1). Additionally, the lowest flexural strength (59.93 MPa) and flexural modulus $(2.57 \mathrm{GPa})$ was seen in the $20 \% \mathrm{MWF}$-added 
composite sample (MPS2). In one study, it has been reported that the flexural strength values of hemp fiber-reinforced composites increased after $1 \%$ and $5 \%$ silane treatment but decreased with $20 \%$ silane treatment. In addition, it has been indicated that the flexural strength and flexural modulus values of hemp fiber-reinforced composites are reduced after treatment with $1 \%$ and $5 \%$ sodium hydroxide (Sepe et al. 2018).

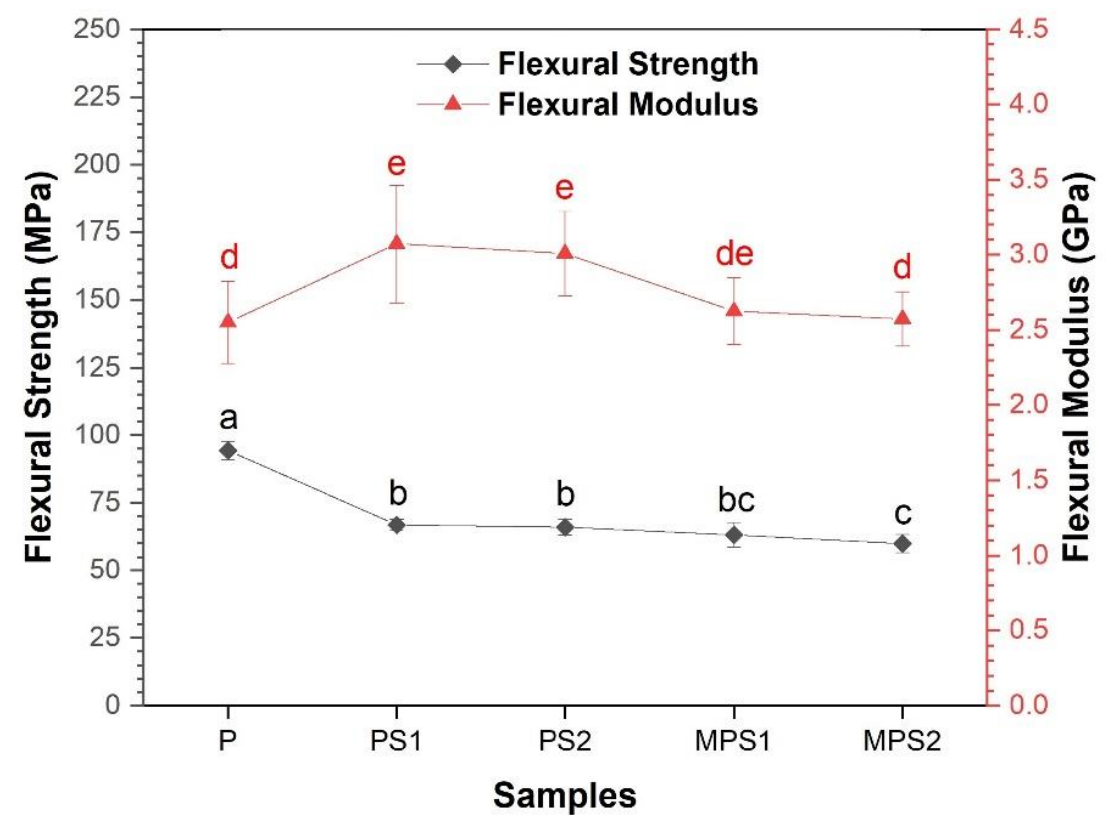

Fig. 4. Flexural strength and modulus of 3D-printed samples

\section{Thermal Properties of 3D-printed Samples}

The thermogravimetric (TG) analysis results and derivative thermogravimetric analysis (DrTGA) curves of 3D-printed samples are given in Fig. 5.

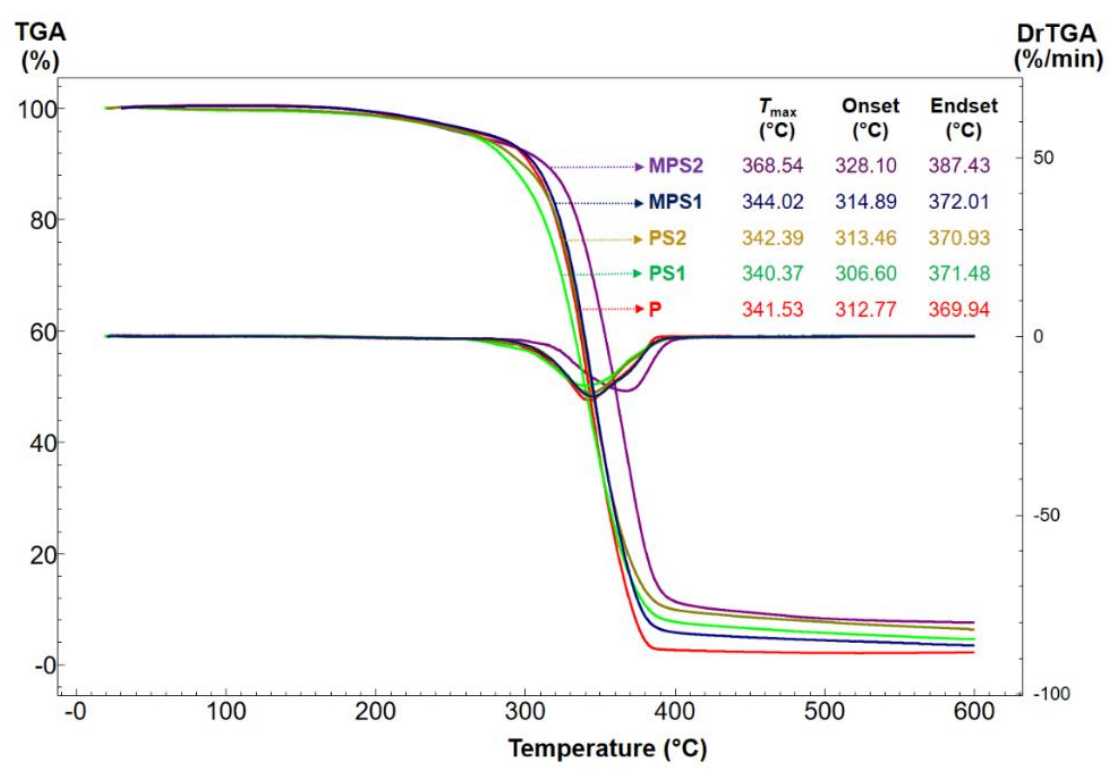

Fig. 5. TGA analysis values and thermograms of 3D printed samples 
As shown, thermal degradation temperatures $\left(T_{\max }\right)$ of the other wood flour-added composites (PS2, MPS1, and MPS2) showed higher values than neat PLA except for the $10 \%$ UMWF-added composite (PS1). In addition, an increase was observed in the decomposition temperature of the $20 \%$ MWF-added composite sample (MPS2). It was seen that this increase was $27.01{ }^{\circ} \mathrm{C}$ higher than neat PLA and it was $26.15{ }^{\circ} \mathrm{C}$ higher than at the same rate of UMWF-added composite sample (PS2). In addition, an increase was observed in the onset and endset temperatures of the MWF-added composites. The modified fibers started to degrade at a higher temperature than unmodified fibers; this indicates that modified fibers are more thermally stable than unmodified ones (Wei et al. 2013). It has been reported that the thermal degradation temperatures of hemp fibers after chemical modification increased by about $15^{\circ} \mathrm{C}$ compared to unmodified ones (Özmen 2012). In other studies, it has been reported that the thermal decomposition temperatures of composites increased as a result of the addition of modified wood/plant fibers into the thermoplastic polymer compared to the neat polymer and unmodified wood/fiber added composites (Özmen et al. 2013; Çetin et al. 2015; Narlığlu 2018). In this study, it is speculated that the degradation of MWF-added composites at higher temperatures compared to UMWF-added composites can be attributed to the reduced free hydroxyl groups after chemical modification.

The DSC heating thermograms of 3D-printed samples from neat PLA and woodPLA composites are shown in Fig. 6.

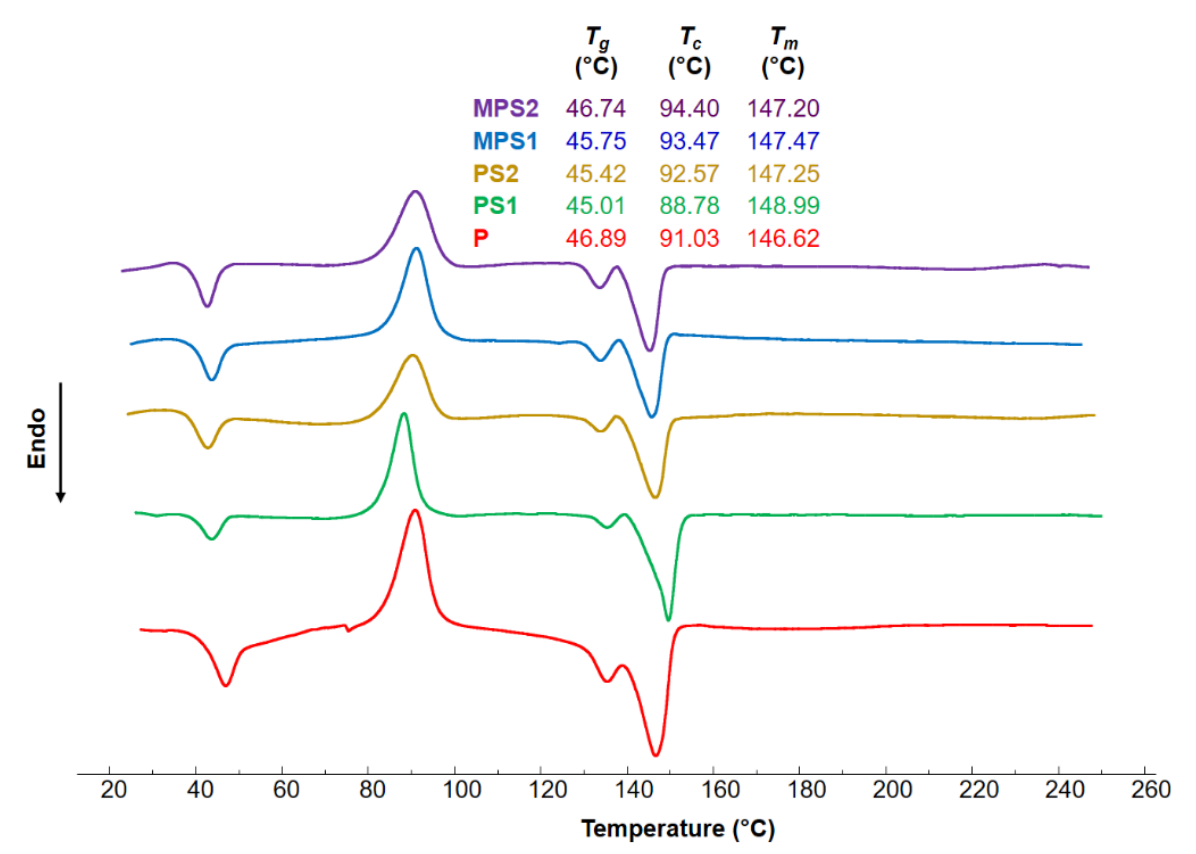

Fig. 6. DSC curves of 3D-printed samples

Additionally, the glass transition temperature $\left(T_{\mathrm{g}}\right)$, melting temperature $\left(T_{\mathrm{m}}\right)$, and crystallization temperature $\left(T_{\mathrm{c}}\right)$ values obtained from DSC analysis are given in Fig. 6. According to the results of DSC analysis, there was a slight decrease in the glass transition temperature with the addition of wood flour to the PLA polymer matrix. In addition, the 20\% MWF-added composite sample (MPS2) exhibited a slightly higher glass transition temperature than the other composites. It has been reported that the melting temperatures 
of PLA do not change after the addition of silane (vinyltrimethoxysilane) to wood fiber (Gregorova et al. 2009). In this study, the degree of melting temperature increased approximately $2{ }^{\circ} \mathrm{C}$ with the addition of $10 \%$ UMWF to PLA. Additionally, the melting temperatures of other composites (PS2, MPS1, and MPS2) were close to each other. In addition, the crystallization temperature of the other composites increased with the addition of wood flour to PLA except for the 10\% UMWF-added composite. It has been reported that changes in $T_{\mathrm{g}}$ are due to the mobility of polymer chains (Abdulkhani et al. 2015). In this study, a change in $T_{g}$ temperatures was observed due to the change in the mobility of the polymer chain with the addition of wood flour to PLA. The changes in $T_{g}$ temperatures are thought to be attributed to wood flour incorporation and chemical modification.

\section{Morphological Properties of 3D-printed Composites}

In Fig. 7, SEM images of the cross-section of the samples with $20 \%$ UMWF-added (PS2) and 20\% MWF-added (MPS2) composites are given. In Fig. 7b, less void was seen in the cross-section of the MWF-added composite (MPS2) as a result of the good encapsulation of the PLA polymer and the wood flour. The voids were attributed to the incompatibility of wood flour and PLA polymer matrix. In this study, it has been shown with SEM images that better stress transfer occurred between the polymer matrix and wood flour due to the good encapsulation of the MWF with the PLA matrix. Additionally, it can be seen from the SEM images that composites had less strength to stress due to the voids seen in the cross-section of the UMWF added composite. In a similar study, SEM micrographs showed that the surface treatment provided good adhesion between the kenaf fiber and the PLA matrix, and the fibers bonded well with the PLA matrix (Huda 2008).

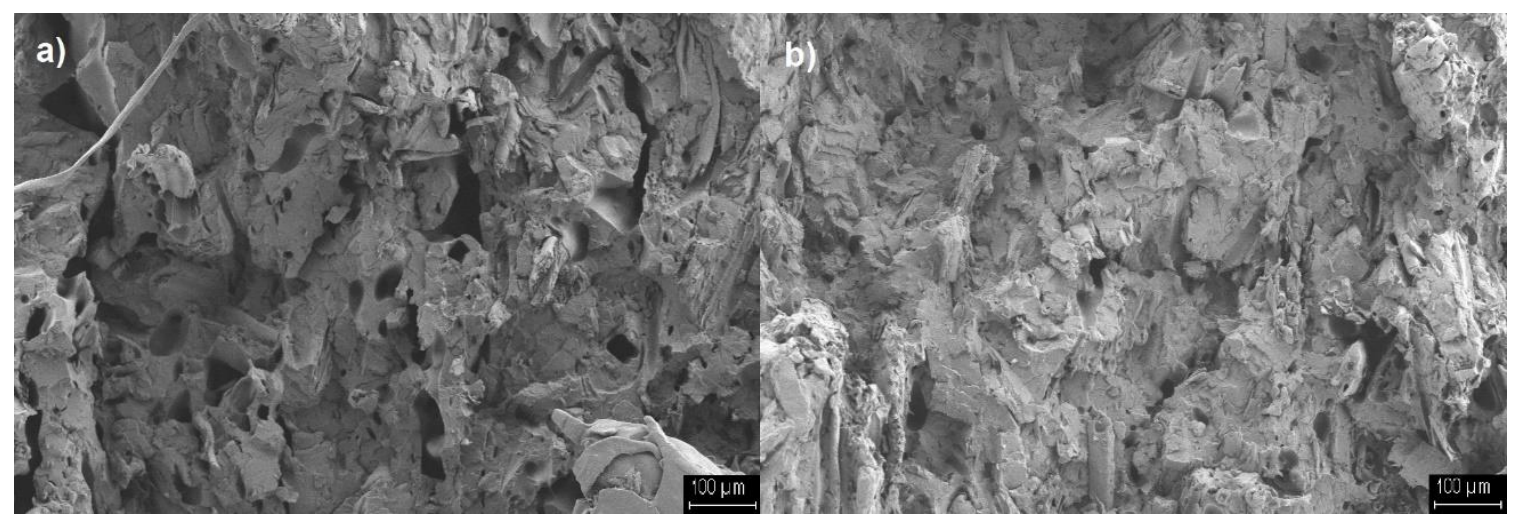

Fig. 7. The SEM images (250x magnification) the cross-sections of 3D-printed composite samples: a) the $20 \%$ UMWF-added composite (PS2), b) the $20 \%$ MWF-added composite (MPS2)

\section{CONCLUSIONS}

1. A $16 \%$ weight percentage gain (WPG) was observed as a result of the modification of Scotch pine wood flour with butyric anhydride.

2. According to the mechanical test results, it was observed that tensile properties of the modified wood flour (MWF)-added composites increased while the flexural properties decreased slightly. This is thought to be attributable to the increase in WPG after butyric anhydride modification of wood flour. 
3. It was observed that the thermal degradation temperature increased as a result of the addition of $20 \%$ MWF to the poly(lactic acid) (PLA) polymer matrix.

4. According to the results of diffential scanning calorimetry (DSC) analysis, a slight increase was seen in the crystallization temperatures after the modification of wood flour while the values were obtained close to each other in the glass transition and melting temperatures.

5. It has been demonstrated in scanning electron microscopy (SEM) images that wood flour has good interfacial bonding with PLA polymer matrix after butyric anhydride modification.

\section{REFERENCES CITED}

Abdulkhani, A., Hosseinzadeh, J., Dadashi, S., and Mousavi, M. (2015). “A study of morphological, thermal, mechanical and barrier properties of PLA based biocomposites prepared with micro and nano sized cellulosic fibers," Cellulose Chemistry and Technology 49, 597-605.

ASTM D638-14 (2014). "Standard test method for tensile properties of plastics," ASTM International, West Conshohocken, PA, USA.

ASTM D790-17 (2017). "Standard test methods for flexural properties of unreinforced and reinforced plastics and electrical insulating materials," ASTM International, West Conshohocken, PA, USA.

Çetin, N. S., Çetin, N., and Harper, D. P. (2015). "Vinyl acetate-modified microcrystalline cellulose-reinforced HDPE composites prepared by twin-screw extrusion," Turkish Journal of Agriculture and Forestry 39(1), 39-47. DOI: 10.3906/tar-1402-115

Çetin, N. S., Özmen, N., and Birinci, E. (2011). "Acetylation of wood with various catalysts," Journal of Wood Chemistry Technology 31(2), 142-153. DOI: 10.1080/02773813.2010.503981

Csizmadia, R., Faludi, G., Renner, K., Móczó, J., and Pukánszky, B. (2013). "PLA/wood biocomposites: Improving composite strength by chemical treatment of the fibers," Composites Part A: Applied Science and Manufacturing 53, 46-53. DOI: 10.1016/j.compositesa.2013.06.003

Estakhrianhaghighi, E., Mirabolghasemi, A., Zhang, Y., Lessard, L., and Akbarzadeh, A. (2020). "3D-printed wood-fiber reinforced architected cellular composites," Advanced Engineering Materials 22(11), article ID 2000565. DOI: 10.1002/adem.202000565

Gregorova, A., Hrabalova, M., Wimmer, R., Saake, B., and Altaner, C. (2009). "Poly (lactide acid) composites reinforced with fibers obtained from different tissue types of Picea sitchensis," Journal of Applied Polymer Science 114(5), 2616-2623. DOI: 10.1002/app.30819

Hill, C. A. S. (2006). "Modifying the properties of wood," in: Wood Modification: Chemical, Thermal and Other Processes, John Wiley and Sons, Ltd., Chichester, England.

Hill, C. A. S., and Jones, D. (1999). "Dimensional changes in corsican pine sapwood due to chemical modification with linear chain anhydrides," Holzforschung 53(3), 267271. DOI: 10.1515/HF.1999.045 
Hill, C. A. S., Hale, M. D., Ormondroyd, G. A., Kwon, J. H., and Forster, S. C. (2006). "Decay resistance of anhydride modified corsican pine sapwood exposed to the brown rot fungus Coniophora puteana," Holzforschung 60(6), 625-629. DOI: 10.1515/HF.2006.105

Huda, M. S., Drzal, L. T., Mohanty, A. K., and Misra, M. (2008). "Effect of fiber surface-treatments on the properties of laminated biocomposites from poly (lactic acid) (PLA) and kenaf fibers," Composites Science and Technology 68(2), 424-432. DOI: 10.1016/j.compscitech.2007.06.022

Kain, S., Ecker, J. V., Haider, A., Musso, M., and Petutschnigg, A. (2020). "Effects of the infill pattern on mechanical properties of fused layer modeling (FLM) 3D printed wood/polylactic acid (PLA) composites," European Journal of Wood and Wood Products 78(1), 65-74. DOI: 10.1007/s00107-019-01473-0

Liu, L., Lin, M., Xu, Z., and Lin, M. (2019). "Polylactic acid-based wood-plastic 3D printing composite and its properties," BioResources 14(4), 8484-8498. DOI: 10.15376/biores.14.4.8484-8498

Narlığlu, N. (2018). Thermoplastic Composite Production from Chemically Modified Lignocellulosics, Ph.D. Dissertation, Kahramanmaras Sutcu Imam University, Kahramanmaras, Turkey.

Narlıoğlu, N., Salan, T., and Alma, M. H. (2021). "Properties of 3D-printed wood sawdust-reinforced PLA composites," BioResources 16(3), 5467-5480. DOI: 10.15376/biores. 16.3.5467-5480

Özmen, N. (2012). "A study of the effect of acetylation on hemp fibres with vinyl acetate," BioResources 7(3), 3800-3809. DOI: 10.15376/biores.7.3.3800-3809

Özmen, N., Çetin, N. S., Mengeloğlu, F., and Birinci, E. (2013). "Vinyl acetate modified scots pine reinforced HDPE composites: Influence of various levels of modification on mechanical and thermal properties," BioResources 8(1), 1361-1373. DOI: 10.15376/biores.8.1.1361-1373

Petchwattana, N., and Covavisaruch, S. (2014). "Mechanical and morphological properties of wood plastic biocomposites prepared from toughened poly (lactic acid) and rubber wood sawdust (Hevea brasiliensis)," Journal of Bionic Engineering 11(4), 630-637. DOI: 10.1016/S1672-6529(14)60074-3

Petchwattana, N., Channuan, W., Naknaen, P., and Narupai, B. (2019). “3D printing filaments prepared from modified poly (lactic acid)/teak wood flour composites: An investigation on the particle size effects and silane coupling agent compatibilisation," Journal of Physical Science 30(2), 169-188. DOI: 10.21315/jps2019.30.2.10

Rowell, R. M. (2006). "Chemical modification of wood: A short review," Wood Material Science \& Engineering 1(1), 29-33. DOI: 10.1080/17480270600670923

Sepe, R., Bollino, F., Boccarusso, L., and Caputo, F. (2018). "Influence of chemical treatments on mechanical properties of hemp fiber reinforced composites," Composites Part B: Engineering 133, 210-217. DOI: 10.1016/j.compositesb.2017.09.030

Spiridon, I., Darie, R. N., and Kangas, H. (2016). "Influence of fiber modifications on PLA/fiber composites. Behavior to accelerated weathering," Composites Part B: Engineering 92, 19-27. DOI: 10.1016/j.compositesb.2016.02.032

Stoof, D., Pickering, K., and Zhang, Y. (2017). "Fused deposition modelling of natural fibre/polylactic acid composites," Journal of Composites Science 1(1), 1-8. DOI: 10.3390/jcs 1010008 
Tserki, V., Zafeiropoulos, N. E., Simon, F., and Panayiotou, C. (2005). "A study of the effect of acetylation and propionylation surface treatments on natural fibres," Composites Part A: Applied Science and Manufacturing 36(8), 1110-1118. DOI: 10.1016/j.compositesa.2005.01.004

Wang, Z., Xu, J., Lu, Y., Hu, L., Fan, Y., Ma, J., and Zhou, X. (2017). "Preparation of 3D printable micro/nanocellulose-polylactic acid (MNC/PLA) composite wire rods with high MNC constitution," Industrial Crops and Products 109, 889-896. DOI: 10.1016/j.indcrop.2017.09.061

Wei, L., McDonald, A. G., Freitag, C., and Morrell, J. J. (2013). "Effects of wood fiber esterification on properties, weatherability and biodurability of wood plastic composites," Polymer Degradation and Stability 98(7), 1348-1361. DOI: 10.1016/j.polymdegradstab.2013.03.027

Yang, Z., Feng, X., Xu, M., and Rodrigue, D. (2020). "Properties of poplar fiber/PLA composites: Comparison on the effect of maleic anhydride and KH550 modification of poplar fiber," Polymers 12(3), article no. 729. DOI: 10.3390/polym12030729

Yang, Z., Feng, X., Xu, M., and Rodrigue, D. (2021). "Printability and properties of 3Dprinted poplar fiber/polylactic acid biocomposite," BioResources 16(2), 2774-2788. DOI: $10.15376 /$ biores. 16.2.2774-2788

Zhang, L., Lv, S., Sun, C., Wan, L., Tan, H., and Zhang, Y. (2017). "Effect of MAH-gPLA on the properties of wood fiber/polylactic acid composites," Polymers 9(11), article no. 591. DOI: 10.3390/polym9110591

Article submitted: June 30, 2021; Peer review completed: September 28, 2021; Revised version received and accepted: November 5, 2021; Published: November 10, 2021. DOI: 10.15376/biores.17.1.132-143 